\title{
The Census of Canada from an Archival Perspective
}

\begin{abstract}
Introduction
With the launch of the census of New France in 1666, Intendant of Justice, Police and Finance Jean Talon began the statistic taking tradition in Canada. The Intendant personally enumerated the 3,215 inhabitants of New France with regards to their age, sex, marital status and occupation. Interested in the characteristics of the inhabitants under his control, the information gathered allowed the Intendant to develop policies that helped the new colony to flourish. As an example, Talon discovered a surplus of men in relation to women. He therefore arranged for young women to be transferred from France, imposed penalties on bachelors and rewarded early marriage and large families. By 1763 , when New France became part of the British Empire, thirty-six full and nine partial censuses had been conducted of the colony. ${ }^{1}$
\end{abstract}

The British colonial government did not have the same census-taking traditions as the French, conducting a census in 1765 , and then only two others before $1800 .^{2}$ Gradually, however, the British government began to institute regular statistical procedures, with an annual census of Upper Canada (now Ontario) starting in 1821, and others conducted less regularly in Lower Canada (now Québec), the Maritimes and the area to become Manitoba. ${ }^{3}$ The first census act was passed in 1841, calling for a quinquennial effort (i.e.: every five years) to determine government, Parliamentary representation based on population (to varying degrees) and the allocation of school grants in Upper and Lower Canada. ${ }^{4}$

Then, in 1847, the Act for taking the Census of this Province and Obtaining Statistical Information Therein established a decennial census (i.e.: every ten years) in Upper and Lower Canada. ${ }^{5}$ The first effort under this new act began in 1851. It is important to note that the census was also used to gather as many different statistics as possible, with questions related to population, agriculture, trades and occupations, housing, public buildings, places of worship, shops, stores, mills, factories and their returns of capital, produce, rent, number of hands employed, and even more diverse topics. ${ }^{6}$ However, the 1851 census was not a complete success. People believed that the information collected would be used to determine taxation, and therefore did not always answer questions truthfully - nor were the commissioners and enumerators fully trained in their duties. For example, the 1851 census listed more living children under one year of age than the total number of births recorded in the previous twelve months. Similar difficulties and errors occurred with the 1861 endeavour. ${ }^{7}$

With the passage of the British North America Act in 1867 and the creation of Canada as a country, both census and general statistics fell under the control of the federal government, with a census to be taken every ten years starting in 1871 . The census was to be used to determine representation by population in the House of Commons and grants to each province to be paid by the federal government. When the Act organizing the Department of Agriculture was passed on 22 May 1868, 'Census, Statistics and the Registration of Statistics' were included in the areas of control. ${ }^{8}$

The Census and Statistics Act of 1879 regularized the decennial census, commencing in 1881. The 1881 effort explored the expanding Canadian nation, as Prince Edward Island, Manitoba and British Columbia had entered Confederation. Concerns with the rapid growth and population change in the West led to the passage of An Act to provide for the taking of a census in the province of Manitoba, the North-West Territories and the District of Keewatin in $1885 .^{9}$

The next decennial census, in 1891, represented another important breakthrough for a different reason - computer equipment was used for the first time. Yes, Herman Hollerith, an American inventor and one of the founders of IBM, had supplied equipment to the 1890 American census and his invention has brought north to Canada for 1891. The minister of Agriculture staidly declared in his report of that year: "In order to expedite the compilation of the immense mass of material, machinery has been employed and a considerable portion of Schedule (number 1) has been compiled and the facts sorted by electrical appliances." 10

The creation of the provinces of Saskatchewan and Alberta in 1905 and the increasingly rapid settlement of the west made the quinquennial census a constitutional requirement 
for the Western provinces in that year. ${ }^{11}$

In 1905, a new Census and Statistics Act fixed the date of the decennial census as June 1911 and every ten years thereafter, and a census of the population and agriculture for the provinces of Manitoba, Saskatchewan and Alberta as June 1916 and every ten years thereafter ${ }^{12}$. Then, in 1912, responsibility for census and statistics was transferred to the department of Trade and Commerce. The new minister, George Eulas Foster, established a Departmental Commission on Official Statistics of Canada. Among other things, the Commission recommended the creation of a centralized statistical office responsible for coordinating and unifying, as well as extending and generally improving the statistical work of the federal government. ${ }^{13}$

A new Statistics Act was passed in 1918, which created the Dominion Bureau of Statistics, with RH Coats as the Dominion Statistician. As with the previous act, the 'Census of the Dominion' was defined as that of population and agriculture, which was to be taken in June 1921, and every ten years thereafter. In 1926, and every ten years thereafter, a census of population and agriculture for Manitoba, Saskatchewan and Alberta was to be taken. The details to be collected in the census were to include the name, age, sex, marital status, nationality, race, education, wage-earnings, religion, profession, houses for habitation, land for agriculture and its use, farm crops, institutions, etc. $^{14}$

The 1921 census asked questions about the birthplaces of mothers and fathers, in order to determine the number of people who had been in the country for more than three generations. A definition of the term 'Canadian' was felt to be increasingly important with Canadian participation in the Versailles Peace Treaty and the League of Nations. ${ }^{15}$ In 1931, the census was used to determine the effects of the Depression with questions related to unemployment - and, where possible, examine the causes of the situation. The census of agriculture was also changed to introduce the concept of abandoned farms, which were was becoming an increasingly familiar sight on the Prairies. ${ }^{16}$

The 1951 census was a new endeavour in the use of 'mark-sense schedules' - mechanically-processed questionnaires on which enumerators simply 'ticked' the correct response. ${ }^{17}$ The content of the questionnaire made a significant effort to examine the changes in the country with the end of the Second World War and the entry of Newfoundland into Confederation. Ten of the twentyfive population schedule questions focussed on the size, composition, characteristics and activity of the labour force. In an attempt to determine the requirements for a fishing questionnaire, a special form was distributed to certain areas to elicit name, address, days spent fishing, and generated income for those involved in the commercial fishing industry. ${ }^{18}$
In 1956, the quinquennial census was extended to all of Canada to monitor the post-war population changes. Only five questions were asked of the whole population, with people informed of the new endeavour through television advertising - another first for the Canadian census world.19

For the 1961 census, the population schedule had a new question related to the level of educational attainment. Twenty percent sampling was also used to collect information related to internal migration, fertility, income characteristics and housing. The 1966 quinquennial census was again extended to the entire country with questions related to name, sex, age, marital status, relationship to head of household and structural type and tenure of dwelling. 20

By 1971, the Dominion Bureau of Statistics was replaced by Statistics Canada - a new agency with new and more powerful legislation that gave increased power to the newly-created 'Chief Statistician' and called for a census of population and agriculture to be taken every five years. The census of that year was also greatly changed in that self-enumeration was introduced for the majority of the population. No longer were enumerators to visit Canadian households, except in the case of the far North and some Native reserves. Instead, forms were delivered to individual households and responses returned by mail. Also, householders found themselves receiving a 'short' or 'long' form - with sampling expanded to the whole of the census. The short form consisted of basic population questions and was received by two-thirds of the population. The long form, sent to the remaining third, consisted of the basic population questions, plus twenty housing and thirty socio-economic questions. ${ }^{21}$

Other changes which have been introduced over the years include the expansion of the term 'head of household' (traditionally believed to be the husband) to include women in 1976, the elimination of the term altogether in 1981, and the enumeration of common-law relationships in 1991. The 1996 census asked questions about aboriginal identity, population group, household activities and mode of transportation to work. ${ }^{22}$

Today, the census represents a massive undertaking, with the 2001 effort counting over thirty-one million Canadians living in some eleven point eight million households. The short questionnaire asked seven basic questions of eighty percent of the population, whereas long forms were sent to the remaining twenty percent who answered an additional fifty-two questions. For about two percent of the population - those in remote locations or on reserves - enumeration still occurs through interview. ${ }^{23}$

\section{Transfers of the Census to the Library and Archives of Canada}

Census of population records have been acquired by the 
National Archives at irregular intervals - the records of the 1871 census entered archival custody in 1941, the 1881 census in 1979 and the 1891 and 1901 returns in 1985. The 1881 release occurred with certain restrictions: microfilm was not allowed to be duplicated for sale, researchers were not to reproduce the names of individuals without the approval of the Dominion Archivist, and 'the incidence of use of the film' was to be noted. Copies of the microfilm were provided to provincial archives under the same conditions. $^{24}$ In 1982, these restrictions were lifted. ${ }^{25}$ The 1901 census was not released until after 92 years had passed (despite being transferred to the archives before that point), in accordance with the regulations of the Privacy Act. ${ }^{26}$ After a period of negotiation, the 1906 census of the Northwest Provinces was transferred to the National Archives and was released to the public in both microfilm form and through our website in January 2003.

Currently, Bill S-13, An Act to Amend the Statistics Act, is before the Senate. This enactment removes a legal ambiguity in relation to access to census records taken between 1910 and 2003. It allows genealogical and historical researchers access to these records under certain conditions for a twenty-year period, beginning ninety-two years after the census took place. One hundred and twelve years after the census, anyone may examine the records without restriction. Also, this Bill proposes that censuses taken after 2006 may be examined by anyone, without restriction, ninety-two years after the taking of the census, if the person enumerated gives consent at the time of census taking.

\section{Macro-appraisal}

The Government Records Branch of the Library and Archives of Canada makes decisions about all records created by the federal government, and obviously census records created by Statistics Canada would fall under this area. In order to add a certain rigour and standardization to the process of determining archival value, the theory of MACRO-APPRAISAL was developed. In the 1991 document "An Appraisal Methodology: Guidelines for Performing an Archival Appraisal" Terry Cook, one of the doctrine's creators, states:

Macro-appraisal moves in a top-down fashion from the purpose or broad societal function of the records creator, through various structures and processes designed to implement that function (and numerous sub-functions), to information systems created to produce and organize records that permit those processes to work, and finally to the records themselves which document all the foregoing as well as the impact of the function and structure on the citizen and, equally important, that of the citizen on the functions and structures.

Evidently, this type of macro-appraisal emphasizes the archival value of the location or site or circumstances of records creation rather than of the records themselves. Its purpose is to assess the capacity of branches or sectors to create records of value in a global way rather than dealing directly, one by one, with the hundreds of records series, databases, and media collections which many large parts of institutions will contain, let alone the thousands of primary file numbers or computer applications. ${ }^{27}$

Thus, when the Library and Archives looks at census records produced by Statistics Canada, any 'appraisal' of the records must include a judgment of how the records work within the structure of the creating department, and the rest of government.

\section{The appraisal situation}

Currently, census of population records are accepted into the custody of the Library and Archives of Canada based on their incredible value to researchers, although a formal appraisal has not yet been made. Given the provisions of Bill S-13, which specify that all census of population records will be transferred to the Library and Archives, a further appraisal will not be required. However, all of the surrounding census data and the census of agriculture will need to be studied.

\section{Census Initiatives at Statistics Canada}

With the 1996 Census of Agriculture and the 2001 Census of Population, Statistics Canada instituted digitization of the questionnaires. Decisions must be made between our two institutions about the preservation of these images and other future initiatives.

Products related to the census are regularly released on the Internet, with Statistics Canada updating the news about Canadians regularly.

The department is also busily trying to get ready for the 2006 initiative.

\section{Census Initiatives at the National Archives}

The Library and Archives is working to digitize the census holdings in its custody, with schedules from 1901 and 1906 currently available on-line. This digitization work is seen as a way to bring popular records into the hands of Canadians and ensure the continued relevance of the Library and Archives into the lives of everyday Canadians. The 1901 and 1906 digitization efforts have been very well received, and continue to be among our most popular web offerings. We can only hope that future census efforts will continue to be as relevant and well-liked by the Canadian public.

In closing, the census can be seen as documents with a past - the long history of their evolution - and a future - through their use for researchers. Hopefully, the agencies entrusted with caring for these records through both these periods can do so in a worthy manner. 


\section{Bibliography}

Coats, RH. "Beginnings in Canadian Statistics." The Canadian Historical Review. June 1946, Volume XXVII, No. 2.

Curtis, Bruce. The Politics of Population: State Formation, Statistics and the Census of Canada, 1840-1875. Toronto: University of Toronto Press, 2001.

Cook, Rupert. Joan Mount. Canadian Statistical Data: An Introduction to Their Interpretation. Sainte-Foy, Quebec: Presses de l’Université du Québec, 1994.

75 Years and Counting: A History of Statistics Canada. Ottawa: Statistics Canada, 1993.

Worton, David A. The Dominion Bureau of Statistics: A History of Canada's Central Statistical Office and its Antecedents, 1841-1972. Montreal: McGill-Queen's University Press, 1998.

\section{Footnotes}

'. Bruce Curtis, The Politics of Population: State Formation, Statistics and the Census of Canada, 1840-1875 (Toronto: University of Toronto Press, 2001). Page 3. 75 Years and Counting: A History of Statistics Canada (Ottawa: Statistics Canada, 1993). Pages 2-4.

2. RH Coats, "Beginnings in Canadian Statistics", The Canadian Historical Review. June 1946, Volume XXVII, No. 2. Pages 113-114.

3. Rupert Cook, Joan Mount, Canadian Statistical Data: An Introduction to Their Interpretation. (Sainte-Foy, Quebec: Presses de l’Université du Québec, 1994). Page 6.

${ }^{4}$. David A Worton, The Dominion Bureau of Statistics: A History of Canada's Central Statistical Office and its Antecedents, 1841-1972 (Montreal: McGill-Queen's University Press, 1998). Pages 46-47.

5. Worton, page 4.

${ }^{6}$. Worton, page 4.

7. 75 years, page 8 .

${ }^{8} .75$ years, page 8.

${ }^{9}$ Worton, pages 24.

${ }^{10}$. Worton, pages 20-21.

${ }^{11}$. Worton, pages 19-20.

12. An Act Respecting the Census and Statistics, Chapter 5, 4-5 Edward VII.
13. 75 years, pages 12-14.

${ }^{14} .75$ years, page 17.

15. Worton, pages 84, 89-91.

16. Worton, page 133.

17. 75 years, page 48 .

18. Worton, pages 244-247.

19. 75 years, pages 67,69 . Worton, pages 247-249.

${ }^{20}$. Worton, pages 288-289.

21. Statistics Canada. "History of the Census of Canada". $<$ http://www12.statcan.ca/english/census01/Info/history. cfm>. 13 May 2003.

22. Statistics Canada. "History of the Census of Canada". $<$ http://www12.statcan.ca/english/census01/Info/history. cfm>. 13 May 2003.

23. Statistics Canada. "History of the Census of Canada". $<$ http://www12.statcan.ca/english/census01/Info/history. cfm>. 13 May 2003.

24. National Archives file 9580-RG31, Volume 1, "Letter to Mr L Fry, Acting Chief Statistician, from WI Smith, Dominion Archivist", 25 April 1980.

25. National Archives file 9580-RG31, Volume 1, "Letter Mr M Swift, Director General from DA Worton, Assistant Chief Statistican”, 10 May 1982.

26. National Archives file 9430-50/S5, Volume 3, "Fax to Claude Beaulé from Jerry O’Brien”, 12 December 1991.

27. Terry Cook, “An Appraisal Methodology: Guidelines for Performing an Archival Appraisal" (National Archives of Canada: 31 December 1991). Page 4.

* Paper presented at the IASSIST 2003 conference in Ottawa, Canada. Cara Downey, Library and Archives of Canada, Cara.Downey@Archives.ca 